\title{
CONCENTRATION AND BIOAVAILABILITY OF FLUORIDE IN MOUTHRINSES PREPARED IN DISPENSING PHARMACIES
}

\author{
CONCENTRAÇÃO E BIODISPONIBILIDADE DO FLUORETO DE ENXAGÜATÓRIOS \\ BUCAIS PREPARADOS EM FARMÁCIAS DE MANIPULAÇÃO
}

Cínthia Pereira Machado TABCHOURY1 , Carla Noujain PIEROBON², Jaime Aparecido CURY ${ }^{3}$

\author{
1- Associate Professor, Area of Biochemistry, Faculty of Dentistry of Piracicaba, UNICAMP. \\ 2- Graduate student, Faculty of of Dentistry of Piracicaba, UNICAMP. \\ 3- Professor, Chairman, Area of Biochemistry, Faculty of Dentistry of Piracicaba, UNICAMP. \\ Corresponding address: Profa. Dra. Cínthia Pereira Machado Tabchoury - Av. Limeira, 901 - Bairro Areião - Faculdade de Odontologia \\ de Piracicaba - UNICAMP - Cep.: 13414-903 - Piracicaba - SP - Fone: (19) 3412-5304/3412-5303 - E-mail: cinthia@fop.unicamp.br \\ Received: February 12, 2004 - Modification: November 17, 2004 - Accepted: November 24, 2004
}

\begin{abstract}
C onsidering the importance of medication quality control and that mouthrinses for dental caries prevention have commonly been prepared in dispensing pharmacies, this study assessed formulations containing $0.05 \%$ NaF acquired from 6 dispensing pharmacies in the city of Piracicaba, S.P. The mouthrinse formulations were purchased in 3 separate periods and coded from A to F. Fluoride ion $\left(\mathrm{F}^{-}\right)$concentration was determined in all formulations in the 3 periods, and in those acquired in the $3^{\text {rd }}$ period, the bioavailability of fluoride with dental enamel with caries-like lesions and the $\mathrm{pH}$ of products were evaluated. A solution of $0.05 \% \mathrm{NaF}$ and distilled deionized water were used, respectively, as positive and negative controls. In the bioavailability analysis, fluoride present in dental enamel was determined removing, by acid etching, two layers of enamel; fluoride in the acid extract was determined with a specific electrode. The mouthrinses prepared in 5 pharmacies presented a $\mathrm{F}^{-}$concentration close to the expected value, except for the product prepared in one of them, in which a mean of $0.01 \%$ NaF was found. All products were more efficient than the negative control $(p<0.05)$ in terms of reactivity with dental enamel, but differences among them were observed with regard to the positive control $(\mathrm{p}<0.05)$. The data suggest that a quality control program should be implemented in dispensing pharmacies to guarantee the quality of fluoridated mouthrinses formulated.

Uniterms: Dispensing pharmacy; Mouthrinse; Fluoride; Dental enamel; Bioavailability.
\end{abstract}

\section{RESUMO}

onsiderando a importância do controle de qualidade de medicamentos e que os enxagüatórios bucais para prevenção da cárie dental tem sido comumente preparados em farmácias de manipulação, este estudo avaliou enxagüatórios contendo NaF 0,05\% adquiridos em 6 farmácias de manipulação na cidade de Piracicaba, SP. Os enxagüatórios foram adquiridos em 3 períodos distintos e codificados de A a F. A concentração de fluoreto $\left(\mathrm{F}^{-}\right)$foi determinada em todas as soluções nos 3 períodos, e naquelas adquiridas no $3^{\circ}$ período, a biodisponibilidade do fluoreto com o esmalte dental com lesão de cárie artificial e o pH dos produtos foram avaliados. Uma solução de $\mathrm{NaF} 0,05 \%$ e água destilada deionizada atuaram, respectivamente, como controle positivo e negativo. Na análise de biodisponibilidade, fluoreto formado no esmalte dental foi determinado após remoção, por ataque ácido, de 2 camadas de esmalte; fluoreto no extrato ácido foi determinado com eletrodo específico. Os enxagüatórios preparados por 5 farmácias apresentaram uma concentração de F- próxima a esperada, com exceção do preparado por uma delas no qual em média foi encontrado $0,01 \% \mathrm{NaF}$. Todos os produtos foram mais eficientes que o controle negativo $(\mathrm{p}<0,05)$ em termos de reatividade com o esmalte dental, mas diferenças entre eles com relação ao controle positivo foram observadas $(p<0,05)$. Os dados sugerem que um programa de controle de qualidade deve ser implementado em farmácias de manipulação para garantir a qualidade dos enxagüatórios fluoretados preparados.

Unitermos: Farmácia de manipulação; Enxagüatório; Fluoreto; Esmalte dentário; Biodisponibilidade. 


\section{INTRODUCTION}

The quality of a pharmaceutical product is one of the fundamental goals to be attained in a standard health system, guaranteeing the patient's benefit and safety. However, errors in dispensing prescriptions have been reported in France $^{21}$ and in the United States ${ }^{28}$. Among these, the most common errors are substitution of the medication on the label and even in the composition ${ }^{28}$.

In Brazil there are also some reports of such problems involving products purchased from dispensing pharmacies. Zuccolotto, et al. ${ }^{33}$ found that $71.4 \%$ of the samples of phytotherapeutic products and vegetable inputs prepared in Porto Alegre, RS, did not meet the minimum quality requirements demanded by the Administrative Ruling No. 6 of the SVSMS (DOU 01/31/95) ${ }^{4}$. Another type of problem that may occur is the interaction of the active agent with components of the formula, resulting in inactivation or decrease of the expected effect. Thus, Rocha, et al. ${ }^{25}$ reported that $1 \%$ chlorexidine gel prepared in a dispensing pharmacy in Piracicaba, SP, was ineffective in reducing the salivary levels of mutans streptococci in patients rehabilited with removable prostheses. The reason for this was explained, because saccharine was used as sweetener and, at a concentration greater than $0.5 \%$, it inhibits the antibacterial activity of chlorexidine digluconate at $1 \%{ }^{10}$. Therefore, problems of this nature may occur with other products prepared in dispensing pharmacies. Currently, Brazilian dispensing pharmacies are adapting themselves to the regulation RDC No. 33, of 04/19/20006.

Fluoridated mouthrinses are relevant as anti-caries agents ${ }^{8}$. Among these, the $0.05 \% \mathrm{NaF}$ mouthrinse for daily use deserves to be mentioned, as it is efficient in controlling caries in patients at high risk, as those under orthodontic treatment ${ }^{12,23}$ or patients that have a physical or motor handicap that prevents them from adequately controlling dental plaque ${ }^{29}$. However, the efficacy of these products does not depend only on the concentration of fluoride in the formula, since the results of Franco and Cury ${ }^{14,15}$ showed that the components of a commercial pre-brushing mouthrinse reduced the reactivity of fluoride with human dental enamel. One of the components of mouthrinses that may reduce the reactivity of fluoride is the anionic detergent sodium lauryl sulphate ${ }^{2}$, which competes with fluoride for dental enamel surface ${ }^{3}$. Thus, problems with concentration and fluoride activity of mouthrinses may occur both with those prepared in dispensing pharmacies and with commercial products.

In this context, Rodrigues, et al. ${ }^{26}$ evaluated the concentration of fluoride ion ( $\mathrm{F}^{-}$) in six commercial brands of mouthrinses present in the Brazilian market, and found that one of them did not comply with the regulation No. 79 of 08/28/2000 of the Ministry of Health's National Sanitary Surveillance Agency ${ }^{5}$, because of presenting around 39\% of the expected concentration (225 ppm F). This problem with commercial mouthrinses was confirmed in another evaluation ${ }^{11}$. Thus, if the products manufactured in Brazil present problems with quality control, the doubt remains when one considers the large number of dispensing pharmacies and the amount of products they put onto the market. Thus, the correct preparation of fluoridated mouthrinses, considering their concentration, stability and compatibility among components, should be assessed.

Therefore, this study aimed at evaluating mouthrinses prepared in dispensing pharmacies, determining the concentration and bioavailability of the fluoride present.

\section{MATERIALAND METHODS}

\section{Sampling and Experimental Design}

Mouthrinses containing $0.05 \% \mathrm{NaF}$ were purchased in 5 private dispensing pharmacies and in a School Pharmacy in the city of Piracicaba, SP, at 3 separate periods. The private pharmacies were chosen due to their central location in the city and by the fact that two of them are responsible for $80 \%$ of the market. In each period, a formula from each establishment was purchased, made up from a prescription given by a dentist, who was not related to the research. The prescription specified the formulation of a fluoridated mouthrinse containing $0.05 \% \mathrm{NaF}$. The products were coded from A to F allowing a blind analysis and also ethically preserving the names of the pharmacies. The concentration of $\mathrm{F}^{-}$ion was determined in all solutions in the 3 periods.

In addition, the $\mathrm{pH}$ of the products and the bioavailability of the fluoride to dental enamel were also assessed in the products purchased in the third period. A $0.05 \% \mathrm{NaF}$ solution was prepared in the laboratory and acted as positive control. Ninety-six blocks of dental enamel with artificial caries lesions were randomly divided into 8 groups of 12 and submitted to the following treatments: distilled deionized water (negative control), $0.05 \% \mathrm{NaF}$ solution and the 6 fluoridated mouthrinses purchased. The concentration of fluoride present in dental enamel was assessed after removal of two layers of enamel by acid etching, followed by an analysis of the extract with a specific electrode.

\section{Determination of $\mathbf{p H}$ and fluoride concentration in mouthrinses}

The $\mathrm{pH}$ of the products purchased in the third period was determined using a pHmeter connected to a $\mathrm{pH}$ electrode, which was calibrated against standard $\mathrm{pH}$ buffers (pH 4.0 and 7.0). The products purchased and the solutions prepared in the laboratory were diluted 20 times and TISAB II (1.0 M acetate buffer, pH 5.0, containing $1.0 \mathrm{M} \mathrm{NaCl}$ and CDTA at $0.4 \%$ ) was added in the proportion of $1: 1^{26}$. The analyses were made in triplicate (variation coefficient lower than $1 \%$ ). The determination of $\mathrm{F}^{-}$was done with a specific electrode ORION 96-06 and ion analyzer EA 940, previously calibrated with standards containing 1.0 to $10.0 \mu \mathrm{g} \mathrm{F} / \mathrm{mL}$, prepared from 100 ppm F standard (ORION 940907). This analysis was made after each acquisition of products. 


\section{Bioavailability of fluoride with dental enamel}

For this evaluation, enamel with caries-like lesions was used because this condition is more suitable in terms of the dose-effect relationship than sound enamel ${ }^{32}$. Blocks of dental enamel measuring 4 x 4 x 2 mm were obtained ${ }^{16}$ from sound bovine incisor teeth that had been stored in a $2 \%$ formaldehyde solution $(\mathrm{pH} \mathrm{7.0)}$ at room temperature for at least 30 days $^{9,31}$.

The enamel surface of the blocks was measured $( \pm$ $0.01 \mathrm{~mm}$ ), and the other surfaces were protected with a layer of acid-resistant varnish. To produce subsurface caries-like lesions, the enamel blocks were immersed for $16 \mathrm{~h}$ in a $0.05 \mathrm{M}$ sodium acetate buffer solution at $37^{\circ} \mathrm{C}$, pH 5.0, 50\% saturated in relation to bovine dental ename ${ }^{24}$. After this period, the enamel blocks were washed with distilled and deionized water and stored in a humid and refrigerated environment $\left(4^{\circ} \mathrm{C}\right)$.

Ninety-six blocks were randomly divided into eight groups of 12 and submitted to the following treatments: six groups for the fluoridated mouthrinses purchased from the dispensing pharmacies and two groups for the positive $(0.05 \% \mathrm{NaF}$ solution prepared in the laboratory) and negative control (distilled deionized water). The reaction time was 10 minutes, the proportion of $1 \mathrm{~mL}$ of solution $/ \mathrm{mm}^{2}$ of exposed enamel surface was standardized, and after the reaction the blocks were washed for $1 \mathrm{~min}$ with distilled deionized water. Two layers of enamel were consecutively removed from each enamel block by immersion in $0.25 \mathrm{~mL}$ of an aqueous solution of $0.5 \mathrm{M} \mathrm{HCl}$ for 15 and 30 seconds under agitation, followed by buffering with the same volume of TISAB II pH 5.0 modified with $20 \mathrm{~g}$ of $\mathrm{NaOH} / \mathrm{L}^{19,22}$. In these extracts, fluoride and inorganic phosphorous $\left(\mathrm{P}_{\mathrm{i}}\right)$ concentrations were determined. The determination of $\mathrm{F}^{-}$was performed using an ion analyzer ORION EA 940 and an ion specific electrode ORION 96-09, previously calibrated with standards of 0.05 to $1.0 \mu \mathrm{g} \mathrm{F} / \mathrm{mL}$. $\mathrm{P}_{\mathrm{i}}$ was determined by the colorimetric method of Fiske and Subbarow ${ }^{13}$. From the amount of $\mathrm{P}_{\mathrm{i}}$ extracted by the acid etching, the mass of enamel removed was calculated, considering a $\mathrm{P}_{\mathrm{i}}$ content in enamel of $17.4 \%{ }^{20}$. Considering the amount of fluoride extracted $(\mu \mathrm{g})$ and the enamel mass (g), the concentration of fluoride in enamel due to the treatments $(\mu \mathrm{g} / \mathrm{g})$ was calculated. An enamel density of $3.0^{20}$ was considered to calculate the thickness of enamel removed (depth of the biopsy).

\section{Statistical Analysis}

The fluoride concentration data and the $\mathrm{pH}$ of the mouthrinses were descriptively analyzed. The results of the thickness of the two layers of enamel were evaluated by analysis of variance (ANOVA). The results of fluoride in enamel were transformed into $\log _{10}$, submitted to ANOVA followed by Newman-Keuls test $(\mathrm{p}<0.05)$. For all these analyses, the program BioEstat $2.0^{1}$ was used and the significance limit was established at $5 \%$.

\section{RESULTS}

Table 1 shows that the mouthrinses prepared in most of the pharmacies presented a fluoride concentration close to the expected value (225ppm of $\mathrm{F}^{-}$) in the formulas bought at the separate periods. However, the same did not occur with Pharmacy A. The first product purchased in this pharmacy presented a concentration 5 times smaller than that expected. The product prepared in the $2^{\text {nd }}$ period again presented a lower fluoride concentration than that mentioned on the label $(0.05 \% \mathrm{NaF})$, which was $0.003 \% \mathrm{NaF}$. In the sample prepared for the $3^{\text {rd }}$ time by Pharmacy A, the $\mathrm{F}^{-}$concentration present was greater than that found in the previous ones, but was still less than the concentration expected and described on the product label. In the positive control solution ( $\mathrm{NaF}$ at $0.05 \%$ ) prepared in the laboratory, $228.2 \mu \mathrm{g}$ $\mathrm{F} / \mathrm{mL}$ (ppm) was found. Table 1 also shows the results of the $\mathrm{pH}$ of the six mouthrinses acquired in the $3^{\text {rd }}$ period and positive control solution, which ranged from 5.64 to 7.16.

Table 2 shows the results of fluoride concentration in enamel after the reaction of the mouthrinses with the enamel blocks, as well as those of the controls, in the two layers of removed enamel. The ANOVA of fluoride in enamel showed

TABLE 1- Fluoride concentration* $(\mu \mathrm{g} / \mathrm{mL})$ found in the 3 formulas of the mouthrinses in each of the periods and mean $( \pm$ standard deviation) and $\mathrm{pH}$ of the mouthrinses purchased in the $3^{\text {rd }}$ period

\begin{tabular}{|c|c|c|c|c|c|}
\hline \multirow[t]{2}{*}{ Pharmacy } & \multicolumn{3}{|c|}{ Periods } & \multirow[t]{2}{*}{ Mean \pm sd } & \multirow[t]{2}{*}{$\mathrm{pH}$} \\
\hline & 1 & 2 & 3 & & \\
\hline Positive control & 223.7 & 227.7 & 233.3 & $228.2 \pm 4.8$ & 6.07 \\
\hline A & 40.7 & 12.2 & 97.0 & $50.0 \pm 43.2$ & 6.44 \\
\hline B & 233.6 & 230.3 & 233.1 & $232.3 \pm 1.8$ & 5.64 \\
\hline C & 223.4 & 233.5 & 231.3 & $229.4 \pm 5.3$ & 6.23 \\
\hline D & 228.9 & 205.8 & 254.9 & $229.9 \pm 24.6$ & 6.88 \\
\hline$E$ & 231.5 & 243.1 & 204.4 & $226.3 \pm 19.9$ & 6.03 \\
\hline$F$ & 209.3 & 227.4 & 221.3 & $219.3 \pm 9.2$ & 7.16 \\
\hline
\end{tabular}

* Expected $225( \pm 10 \%) \mu \mathrm{g} / \mathrm{mL}$, accordingto Brazilian guidelines ${ }^{5}$ 
significance for the treatment in each layer $(\mathrm{p}<0.05)$. In the $1^{\text {st }}$ layer, all treatments showed differences when compared to the negative control $(\mathrm{p}<0.05)$; the products prepared in Pharmacies A, D and F presented reactivity equal to that of the positive control, while those from Pharmacies B, C and E presented statistically greater reactivity than that of the positive control. In the $2^{\text {nd }}$ layer, the concentration of fluoride in the enamel due to reaction with the negative control was statistically different from that due to all other treatments, except for the products from Pharmacies D and F ( $>>0.05$ ). The products prepared in Pharmacies B, C and E presented reactivity similar to the positive control. The distance from the surface of each enamel layer removed is shown as mean, as the difference between the treatments was not statistically significant $\left(1^{\text {st }}\right.$ layer $\mathrm{p}=0.5027 ; 2^{\text {nd }}$ layer $\left.\mathrm{p}=0.2392\right)$.

\section{DISCUSSION}

The findings showed that the fluoridated mouthrinses purchased from the dispensing pharmacies presented differences in their formulas (Table 1), as the product prepared in Pharmacy A presented problems in its formula with regard to fluoride concentration in the three periods analyzed. Even though this fact was presented by only one of the pharmacies, in terms of consumers' rights this fact is relevant even if it puts in risk the health of only one citizen. Furthermore, this suggests that consumers are purchasing products that have been manipulated in an incorrect manner. These incorrectly dispensed products could include not only the fluoridated mouthrinses herein presented, but also other medications that are of indispensable use to the patient. The cause of the error in preparing a $0.05 \% \mathrm{NaF}$ solution may include factors starting with impure raw material through to the use of an un-calibrated balance. The problem

TABLE 2- Concentration ( $\mu \mathrm{g} / \mathrm{g} \pm$ standard error) of fluoride in dental enamel according to the treatments and the removed layer

$\begin{array}{ll}\text { Treatment } & \text { Distance from the surface }(\mu \mathrm{m} \pm d p) \\ & 8.2 \pm 2.2(n=10) \\ \end{array}$

$\begin{array}{lll}\begin{array}{l}\text { Negative } \\ \text { control }\end{array} & 623.6 \pm 75.8^{\mathrm{a}} & 599.1 \pm 168.4^{\mathrm{a}} \\ \text { A } & 2735.6 \pm 252.4^{\mathrm{b}} & 915.8 \pm 165.4^{\mathrm{bc}} \\ \text { B } & 4174.2 \pm 216.2^{\mathrm{c}} & 1582.3 \pm 211.8^{\mathrm{d}} \\ \text { C } & 4548.9 \pm 284.6^{\mathrm{c}} & 1802.5 \pm 260.1^{\mathrm{d}} \\ \text { D } & 3148.9 \pm 156.0^{\mathrm{b}} & 853.9 \pm 123.4^{\mathrm{abc}} \\ \text { E } & 4740.2 \pm 261.9^{\mathrm{c}} & 1385.8 \pm 216.9^{\mathrm{cd}} \\ \text { F } & 2391.9 \pm 121.5^{\mathrm{b}} & 745.8 \pm 96.9^{\mathrm{ab}} \\ \text { Positive } & & \\ \text { control } & 2677.9 \pm 169.4^{\mathrm{b}} & 1849.8 \pm 619.6^{\mathrm{d}}\end{array}$

Treatments whose means are followed by different letters differ statistically by the Newman-Keuls test $(p<0.05)$. with raw material would be of lesser importance in comparison with that of weighing, as the same balance may be used for weighing other pharmaceutical substances. The current legislation ${ }^{6}$ establishes that a dispensing pharmacy must present a quality control laboratory to analyze, among others, the amount of active substance, and the equipment needs to be periodically verified and calibrated.

With regard to the capacity of fluoride present in the mouthrinses to react with dental enamel (Table 2), all products presented bioavailable fluoride ready to be incorporated by enamel with caries-like lesions, including that from Pharmacy A, which presented formulation problems (Table 1), as all groups differed statistically from the negative control $(\mathrm{p}<0.05)$. However, differences among the products themselves and in relation to the positive control were observed. Thus, some of these fluoridated mouthrinses, whose fluoride concentration was close to that mentioned on the label, presented statistically greater reactivity than the positive control in the first layer of enamel removed, and this result is surprising at a first glance. There may be two explanations for the greater reactivity of the mouthrinses prepared in Pharmacies B, C and E in relation to the positive control: (1) these products would have a lower $\mathrm{pH}$ than the fluoridated solution prepared in the laboratory, which would positively influence the reactivity of fluoride with dental enamel as, according to Saxegaard and Rölla ${ }^{27}$, the decrease in $\mathrm{pH}$ of a solution of $0.48 \mathrm{~mol} / \mathrm{L} \mathrm{NaF}$ from 7.0 to 5.5 causes an increase of 4 times in the reactivity of fluoride with dental enamel. The $\mathrm{pH}$ of the different solutions analyzed was determined and there was no relationship between lower $\mathrm{pH}$ values and greater reactivity. The $\mathrm{pH}$ values of solutions ranged from 5.64 (mouthrinse $B$ ) to 7.16 (mouthrinse $F$ ). This may explain the greater reactivity of the mouthrinse $B$ $(\mathrm{p}<0.05)$, but, the $\mathrm{pH}$ of the positive control solution was 6.07 and the $\mathrm{pH}$ of mouthrinse $\mathrm{C}$ was 6.23 , which would not explain its greater reactivity $(\mathrm{p}<0.05)$.

Another explanation would be that the substances present in the mouthrinses could increase fluoride reactivity. There have been reports of increase of fluoride incorporation in dental enamel in the presence of surface agents $s^{7,17}$. Assessing the product labels in this study, it was noted that Nipagin (methylparaben), a preservative, was listed in the composition of the mouthrinses prepared in Pharmacies $\mathrm{B}$ and $\mathrm{C}$, exactly two of the three products that presented greater reactivity. As methylparaben absorbs light at 250nm, absorption spectra of the mouthrinses were traced in a spectrophotometer. Those coded as B, C, E and a solution of methylparaben at $0.2 \%$ prepared in the laboratory presented similar spectras with a peak close to $250 \mathrm{~nm}$. Mouthrinses A, D, F and the fluoridated solution prepared in the laboratory, which contained only $\mathrm{NaF}$, did not present this peak at 250nm. Thus, the three mouthrinses, which presented the greatest values of fluoride bioavailability with dental enamel in relation to the first layer, also presented the absorption spectra indicative of the presence of methylparaben. These results suggest that new studies should be carried out, in order to confirm this effect of methylparaben and in addition, try to explain its mechanism 
of action.

The results of greater fluoride bioavailability of the products prepared in Pharmacies B, C and E were not repeated in the second layer, suggesting that methylparaben could only increase the amount of fluoride formed close to the surface. This kind of fluoride formed could be " $\mathrm{CaF}_{2}$ "like, which is considered the product responsible for the anti-caries effect of the topical methods of fluoride use $\mathrm{e}^{27,30}$. Thus, research differentiating the type of fluoride formed in dental enamel should be conducted.

\section{CONCLUSION}

In summary, the data suggest that most of the products evaluated were adequately prepared and with bioavailable $\mathrm{F}$, but a process of quality control should be implemented in dispensing pharmacies.

\section{ACKNOWLEDGEMENTS}

To Ms Marisa J. C. Soares and Mr. Waldomiro Vieira Filho, technicians of the Oral Biochemistry Laboratory of FOP-UNICAMP, for their valuable help with the laboratory analyses. To FAPESP, from whom the first author received a grant (proc. 1998/11929-9) and the second author received a scholarship during her undergraduation course in Dentistry at FOP-UNICAMP (proc. 1998/11657-9).

\section{REFERENCES}

1- Ayres M, Ayres MJr, Ayres DL, Santos SA. BioEstat 2.0: Aplicações estatísticas em Ciências Biológicas e Medicina. Belém, Sociedade Civil Mamirauá, Brasília, CNPq, 2000.

2- Barkvoll P. Effect of sodium lauryl sulfate on the uptake of fluoride from NaF and MFP by etched enamel in vitro. J Biol Bucc 1991;19:235-9.

3- Barkvoll P, Rölla G, Lagerlöf F. Effect of sodium lauryl sulfate on the deposition of alkali-soluble fluoride on enamel in vitro. Caries Res 1988;22:139-44.

4- Brasil. Ministério da Saúde. Secretaria de Vigilância Sanitária. Resolução - Portaria nº 6, de 31 de janeiro de 1995.

5- Brasil. Ministério da Saúde. Agência Nacional de Vigilância Sanitária. Resolução - RDC nº 79, de 28 de agosto de 2000

6- Brasil. Ministério da Saúde. Agência Nacional de Vigilância Sanitária. Resolução - RDC nº 33, de 19 de abril de 2000 .

7- Caslavska V, Gron P. Effect of surface-active agents on fluorideenamel interactions.I Caries Res 1983; 17:221-8.

8- Cury JA. Uso do flúor e controle da cárie como doença. In: Baratieri LN. Odontologia restauradora: fundamentos e possibilidades. São Paulo: Editora Santos; 2001. p.31-68.

9- Cury JA, Rebelo MAB, Del Bel Cury AA, Derbyshire MTVC, Tabchoury CPM. Biochemical composition and cariogenicity of dental plaque formed in the presence of sucrose or glucose and fructose. Caries Res 2000a; 34:491-7.
10- Cury JA, Rocha EP, Koo H, Francisco SB, Del Bel Cury AA. Effect of saccharin on antibacterial activity of chlorhexidine gel. Braz Dent J 2000b; 11:29-34.

11 - Delbem ACB, Sassaki KT, Castro AM, Pinto LMCP, Bergamaschi $\mathrm{M}$. Assessment of the fluoride concentration and $\mathrm{pH}$ in different mouthrinses on the Brazilian market. J Appl Oral Sci 2003;11:31923.

12 - FDI Commission. Mouthrinses and dental caries. Int Dent J 2002; 52:337-45.

13- Fiske CH, Subbarow Y. The colorimetric determination of phosphorus. J Biol Chem 1925; 66:375-400.

14- Franco EM, Cury JA. Bochecho com Plax ${ }^{\circledR}$ e reatividade do flúor. RGO 1993;41:283-6.

15- Franco EM, Cury JA. Effect of Plax prebrushing rinse on enamel fluoride deposition. Am J Dent 1994;7:119-21.

16- Fushida CE, Cury JA. Estudo in situ do efeito da freqüência de ingestão de coca-cola na erosão do esmalte-dentina e reversão pela saliva. Rev Odontol Univ São Paulo 1999;13:127-34.

17- Gron P, Caslavska V. Effect of surface-active agents on fluoride enamel interactions.II Caries Res 1983;17:304-9.

18- Helou JK, Cimino JS, Daffre C. Farmacotécnica. São Paulo:Editora Artpress, 1975.

19- Koo H, Cury JA. Soluble calcium/SMFP dentifrice: effect on enamel fluoride uptake and remineralization. Am J Dent 1998;11:1736

20- Lazzari EP. Dental Biochemistry. 2.ed. London: Henry Kimpton Publishers, 1976.

21-Limat S, Drouhin JP, Demesmay K, Tissot E, Jacquet M, Woronoff-Lemsi MC. Incidence and risk factors of preparation errors in a centralized cytotoxic preparation unit. Pharm World Sci 2001;23:102-6.

22- Maia LC, De Souza IP, Cury JA. Effect of a combination of fluoride dentifrice and varnish on enamel surface rehardening and fluoride uptake in vitro. Eur J Oral Sci 2003;111:68-72.

23-Øgaard B, Seppä L, Rölla G. Professional topical fluoride applications - clinical efficacy and mechanism of action. Adv Dent Res 1994;8:190-201.

24- Paes Leme AF, Tabchoury CPM, Zero DT, Cury JA. Effect of fluoridated dentifrice and acidulated phosphate fluoride application on early artificial carious lesion. Am J Dent 2003;16:91-5.

25- Rocha EP, Francisco SB, Del Bel Cury AA, Cury JA. Longitudinal study of the influence of removable partial denture and chemical control on the levels of Streptococcus mutans in saliva. J Oral Rehabil 2003;30:131-8.

26- Rodrigues LKA, Dalcico R, Gomes VE, Zanin ICJ, Nascimento MM, Duarte S. Análise de flúor em enxagüatórios bucais encontrados no comércio brasileiro e o uso de eletrodo íon-específico. RPG Rev Pos Grad 2002;9:142-8.

27- Saxegaard E, Rölla G. Fluoride acquisition on and in human enamel during topical application in vitro. Scand J Dent Res 1988;96:52335.

28- Seifert AS, Jacobitz K. Pharmacy prescription dispensing errors reported to a regional poison control center. J Toxicol Clin Toxicol 2002;40:919-23. 
29- Stephen KW. Fluoride toothpastes, rinses, and tablets. Adv Dent Res 1994;8:185-9.

30 - Ten Cate JM. Review on fluoride, with special emphasis on calcium fluoride mechanisms in caries prevention. Eur J Oral Sci $1997 ; 105: 461-5$.

31- White DJ. Reactivity of fluoride dentifrices with artificial caries I. Effect on early lesions: F uptake, surface hardening and remineralization. Caries Res 1987;21:126-40.

32- White DJ. The application of in vitro models to research on demineralization and remineralization of the teeth. Adv Dent Res 1995;9:175-93.

33- Zuccolotto T, Apel M, Rates SMK. Avaliação da qualidade de produtos fitoterápicos comercializados em Porto Alegre-RS. Rev Inst Adolf Lutz 1999;50:25-31. 
O arquivo disponível sofreu correções conforme ERRATA publicada no Volume 13 Número 2 da revista. 